\section{Ks. Paweł Podeszwa}

Uniwersytet im. Adama Miskiewicza, Poznań podpaw@amu.edu.pl

DOI: http://dx.doi.org/10.12775/BPTh.2016.010

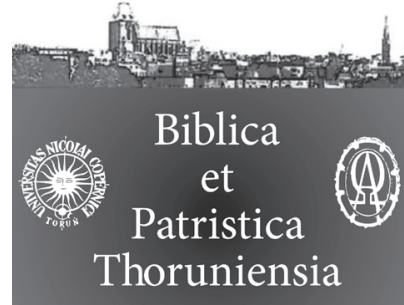

9 (2016) 1: 171-177

ISSN (print) 1689-5150

ISSN (online) 2450-7059

\title{
Recenzja: T. Tułodziecki, Tożsamość nowego Izraela w Księdze proroka Zachariasza. Studium egzegetyczno-teologiczne Za 1-8, Scripta Theologica Thoruniensia 33, Toruń 2014, ss. 340
}

\section{$\dot{\mathrm{Z}}$}

yjemy w świecie globalizacji i niezwykle szybkich przemian, obejmujących niemal wszystkie dziedziny i obszary ludzkiej egzystencji. Zwłaszcza łatwość migracji oraz coraz bardziej nasilający się problem uchodźców, skłaniają niejednokrotnie człowieka do refleksji nad własną tożsamością historyczną, narodową, kulturową czy religijną. Szczególnie w poczuciu zagrożenia, konfliktów, sporów i kontrowersji, poszukiwanie własnej tożsamości z jednej strony daje odpowiedź na pytanie o niezmienne wartości o niej decydujące i z których nie wolno zrezygnować, aby ją zachować, z drugiej jednak strony odwoływanie się do tożsamości może służyć usprawiedliwianiu i obronie własnych interesów, czy nawet własnych wyobrażeń o wartościach kulturowych i religijnych, które z kolei uznane za jedynie prawdziwe mają stać się obowiązujące dla wszystkich bez wyjątku. Pogłębiona refleksja nad problematyką tożsamości jest zatem niezwykle potrzebna i bardzo aktualna. W ten nurt wpisuje się monografia ks. Tomasza Tułodzieckiego, biblisty, adiunkta Wydziału Teologicznego Uniwersytetu Mikołaja Kopernika w Toruniu, zatytułowana Tożsamość nowego Izraela $w$ Księdze proroka Zachariasza. Studium egzegetyczno-teologiczne Za 1-8, wydana w serii „Scripta Theologica Thoruniensia” (33), przez Wydawnictwo Naukowe tegoż Uniwersytetu. Podejmuje ona niezwykle ciekawe zagadnienie tożsamości biblijnego Izraela, a zwłaszcza postulatów proroka Zachariasza, który świadomy wielu zagrożeń po niewoli babilońskiej, zachęca naród wybrany do odnowienia ufności względem Boga i trwania w Przymierzu, co jest gwarancją odbudowy narodowej i religijnej oraz zachowania tożsamości.

Recenzowana książka składa się z „Wprowadzenia” oraz trzech rozdziałów, noszących tytuły: 1. „Problem tożsamości Izraela w okresie przedwygnaniowym i w czasie niewoli babilońskiej”; 2. „Problemy literackie Za 1-8”; 3. „Podstawy tożsamości nowego Izraela w cyklu nocnych wizji Proto-Zachariasza (1,7-6,14); „Zakończenia”, „Wykazu skrótów” oraz „Bibliografii”. Struktura publikacji jest logiczna. Każdy rozdział rozpoczyna się krótkim wprowadzeniem, 
gdzie Autor jasno tłumaczy zasadność podejmowanych wywodów, kończy się zaś syntetycznym podsumowaniem, zawierającym podstawowe wnioski z analizowanych tekstów. Moim zdaniem uzasadnione byłoby dołączenie czwartego rozdziału, który sumarycznie zbierałby wnioski teologiczne $\mathrm{z}$ analizowanych tekstów Proto-Zachariasza, jednoznacznie odpowiadając na pytanie: na ile owa tożsamość nowego Izraela postulowana przez proroka jest kontynuacją podstawowych elementów, składających się na tożsamość narodu wybranego sprzed niewoli, a na ile prorockie nauczanie wnosi istotne novum $\mathrm{w}$ jej rozumienie? W zakończeniu książki Autor stwierdza krótko, że „novum Księgi Zachariasza w ukazywaniu tożsamości dla nowego Izraela polega na jeszcze silniejszym podkreślaniu przesłania o tym, że jej przyjęcie nie jest zarezerwowane tylko dla Żydów, ale zgodnie ze słowami zawartymi w 8,20-23 powinna ona stać się programem życia w perspektywie uniwersalnej” (s. 320). Uważam, że ten wątek domagałby się rozwinięcia oraz szerszego uzasadnienia. Szkoda także, że Autor nie zdecydował się umieścić na końcu książki streszczenia w języku obcym, które dawałoby możliwość zapoznania się szerszemu gronu czytelników z głównymi ideami publikacji oraz promowałoby polską myśl biblijną i teologiczną w świecie.

Publikację otwiera „Wprowadzenie” (s. 11-22). Jest ono napisane poprawnie i zawiera wszystkie niezbędne elementy. Autor rozpoczyna od syntetycznego zaprezentowania problematyki związanej z tożsamością Izraela oraz jej specyfiki, wynikającej z „wyjątkowego kodu kulturowego, którym jest Tora, zdolna przekształcić biblijny Izrael we wspólnotę oddaną tylko Bogu i zachowującą w życiu codziennym inne od pozostałych wspólnot reguły postępowania, zarówno w wymiarze społecznym, rodzinnym, jak i religijnym" (s. 13). Zwięźle ukazuje także kontekst historyczny końca niewoli babilońskiej wraz z charakterystycznymi problemami, z którymi borykał się naród wybrany w tym szczególnym momencie swojej historii. Zaznacza szczególną rolę proroków, zwłaszcza Aggeusza i Zachariasza, którzy nie tylko są gorącymi zwolennikami odbudowy świątyni, ale starają się nakreślić nowe zadania przed odradzająca się wspólnotą religijną i narodową. Zdaniem Autora szczególną zasługę w promowaniu nowej tożsamości powygnaniowego Izraela ma Proto-Zachariasz, definiujący ją za pomocą siedmiu nocnych wizji $(1,7-6,14)$. Autor jasno precyzuje i określa cel publikacji: „dotarcie do sedna Bożego przesłania zawartego w cyklu nocnych wizji Proto-Zachariasza, który wydaje się jednocześnie wspaniałą Bożą propozycją prawdziwej tożsamości dla nowego Izraela, powstającego z gruzów i niewoli” (s. 16-17). Następnie ks. Tułodziecki omawia "status quaestionis”, wskazując najważniejsze opracowania, podejmujące bezpośrednio lub pośrednio zaproponowaną tematykę. Przegląd najważniejszych publikacji naukowych prowadzi do słusznego wniosku, że zagadnienie ustalenia istotnych elemen- 
tów nowej tożsamości Izraela w oparciu o wskazane wyżej wizje prorockie nie zostało wyczerpująco opracowane, a zatem otwiera się wystarczająco szerokie pole do podjęcia zaproponowanego tematu. Kolejnym ważnym elementem każdego „Wprowadzenia” jest wskazanie metody badawczej. Autor słusznie zauważa, że lektura historyczna i teologiczna tekstu biblijnego domaga się użycia metody historyczno-krytycznej, która łączy w sobie analizę diachroniczną i synchroniczną (zob. s. 21). Rzeczywiście w całym studium, zwłaszcza analizie egzegetycznej cyklu nocnych wizji, Autor z powodzeniem i konsekwentnie stosuje obraną metodę badawczą. We „Wprowadzeniu” stwierdza także „jakkolwiek do właściwego ukazania przesłania poszczególnych tekstów wchodzących w skład nocnego cyklu wizji Zachariasza będą wykorzystane procedury metody historyczno-krytycznej, to całe opracowanie zostanie oparte raczej na innym rodzaju studium teologicznego, które w skrócie można określić jako konceptualne" (s. 21). Szkoda, że Autor nie wyjaśnił dokładniej czytelnikowi, co ma tutaj na myśli i co kryje się pod tym skrótowym określeniem „teologiczne studium konceptualne”. Ostatnią część „Wprowadzenia” stanowi zwięzła prezentacja struktury pracy oraz syntetyczne omówienie zawartości kolejnych trzech jej rozdziałów.

Rozdział pierwszy, zatytułowany „Problem tożsamości Izraela w okresie przedwygnaniowym i w czasie niewoli babilońskiej” (s. 23-96) ma charakter wprowadzający w problematykę tożsamości Izraela. Analizując kolejne etapy historii narodu wybranego, począwszy od Patriarchów, poprzez wyjście z niewoli egipskiej oraz zawarcie Przymierza na Synaju, czas monarchii i podzielonego Izraela aż po działalność proroków przedwygnaniowych i podczas niewoli babilońskiej, Autor stara odpowiedzieć się na pytanie o istotne elementy, które decydowały i miały wpływ na tożsamość Izraela w omawianych okresach. Słusznie zauważa, że tożsamość Izraela rozumiana jako szczególna i niepowtarzalna relacja $z$ Bogiem i innymi ludźmi ma swoje początki w historii Patriarchów, zwłaszcza przymierzu z Abrahamem. Została następnie na nowo zdefiniowana i umocniona Przymierzem na Górze Synaj, a Kodeks Przymierza (Wj 19,1-24,18) uznany został jako jej prawna podstawa. Kryzys tożsamości spowodowany upadkiem monarchii i podziałem stał się wyzwaniem dla proroków, którzy podjęli walkę o zachowanie tożsamości mimo zewnętrznych i wewnętrznych problemów, a także starali się ją ocalić i zrewidować, zwłaszcza kiedy legła w gruzach Jerozolima i Świątynia, a naród wybrany znalazł się w niewoli babilońskiej. Rozdział ten jest jak najbardziej zasadny i potrzebny, aby uświadomić czytelnikowi, że tożsamość Izraela kształtowała się przez wielkowiekowe doświadczenie, będące owocem objawiania się Boga i wychowywania Izraela jako swojego ludu. Pozwala on także zrozumieć, że Proto-Zachariasz kontynuuje dzieło licznych proroków Starego Testamentu, którzy w zmieniającej się 
sytuacji narodu wybranego uświadamiali ludowi to, co powinno pozostać fundamentalne i nienaruszone dla podtrzymywania i umacniania relacji z Bogiem i drugim człowiekiem. Jedyny problem - pytanie, który pojawia się przy lekturze tego rozdziału jest natury metodologicznej. Czy można uznać teksty, przynajmniej wiele z nich, zwłaszcza te mówiące o Patriarchach, w których widzimy wyraźny wpływ późniejszych tradycji na formę literacką, ale zwłaszcza teologię tekstu, za wiarygodne źródła do poznania faktycznie tożsamości Izraela w czasach Patriarchów? Autor jest jednak świadomy tego problemu, kiedy stwierdza „jest to tradycja stosunkowa młoda, powstała z pewnością po niewoli babilońskiej, a więc w czasach współczesnych prorokowi Zachariaszowi lub w epoce jeszcze późniejszej. Tym samym należałoby ją traktować jako źródło recepcji myśli tego proroka" (s. 40).

Drugi rozdział został poświęcony wyłącznie Księdze Zachariasza. Zatytułowany „Problemy literackie Za 1-8” (s. 97-173) jest bardzo logicznie zbudowany. Autor rozpoczyna od omówienia kontekstu historycznego wystąpienia Zachariasza, odwołując się do świadectw wewnętrznych. Następnie precyzyjnie przy pomocy kryterium stylu, rodzaju literackiego oraz tematycznego udowadnia zasadność podziału Księgi na dwie zasadnicze części: Proto-Zachariasza (Za 1-8) i Deutero-Zachariasz (Za 9-14), uznając tym samym, że szukając „podstaw tożsamości, czyli pewnego kodu kulturowo-religijnego i kanonu zachowań, jaki miał obowiązywać w Izraelu w pierwszych dziesięcioleciach po odzyskaniu niepodległości w 538 r. przed Chr., to należy to czynić w oparciu o tekst zawarty w dziele Proto-Zachariasza (1-8). To tam znajduje się odwołanie do trudnych momentów historii związanych z repatriacją, przejmowaniem władzy w Judzie i odbudową świątyni” (s. 104). Po omówieniu możliwych relacji formalnych i treściowych między Księgą Aggeusza i Proto-Zachariaszem, które prowadzą do konkluzji, że podobieństwa chronologiczne i terminologiczne, teologiczne i tematyczne, wskazują, iż mamy do czynienia $\mathrm{z}$ „bardzo przemyślanym dziełem" (s. 114), Autor koncentruje swoją uwagę już wyłącznie na Za 1-8, dokonując bardzo rzetelnej analizy literackiej, na podstawie której wykazuje inkluzyjną pozycję Za 1,1-6 oraz 7,1-14 i konkluzyjny charakter Za 8,1-23. Następnie ks. Tomasz poświęca sporo miejsca kompozycji cyklu wizji Proto-Zachariasza i w oparciu o poprawnie przyjęte kryteria proponuje ich koncentryczną strukturę. Zauważona struktura koncentryczna pozwala na słuszny wniosek, że centralną i najważniejszą wizją tego bloku jest apokaliptyczny obraz „złotego świecznika” (Za 4,1-14), stanowiący IV wizję cyklu, a pozostałe wizje tworzą trzy pary (I i VII; II i VI,; III i V) paralelnych obrazów o podobnej do siebie tematyce teologicznej. Zarówno struktura rozdziału, jego treść, jak i sposób prezentacji materiału w poszczególnych paragrafach, nie budzą żadnych zastrzeżeń. Należy zauważyć, że Autor konsekwentnie podażą 
obraną drogą, nie snuje rozważań, które zaciemniałyby główny wątek prowadzonych badań.

Rozdział trzeci nosi tytuł „Podstawy tożsamości nowego Izraela w cyklu nocnych wizji Proto-Zachariasza (1,7-6,14)" (s. 175-313). Jest on najobszerniejszy i kluczowy dla podjętej problematyki, gdyż zawiera szczegółową analizą egzegetyczną i teologiczną poszczególnych wizji. Autor konsekwentnie trzyma się ustalonej wcześniej struktury koncentrycznej cyklu, wynikiem czego są cztery kolejne paragrafy, stopniowo odsłaniające prorocką propozycję tożsamości nowego Izraela: 1) wizja pierwsza i siódma - perspektywa przygotowawcza pod projekt nowej tożsamości i odnowy; 2) wizja druga i szósta - kontynuacja perspektywy oczyszczenia oraz usunięcia zła i grzechu zawężająca ją do przestrzeni Świętego Miasta Jeruzalem wraz ze Świątynią; 3) wizja trzecia i piąta - zawierające przesłanie o wypełnieniu świętej przestrzeni konkretnymi wartościami; 4) wizja czwarta - ukazująca „złoty świecznik i dwie oliwki”. Zasadniczo schemat prezentacji poszczególnych wizji opiera się na ich strukturze, składającej się z trzech elementów: a) opisu tego, co widział prorok; b) pytania proroka o znaczenie obrazu; c) odpowiedzi udzielonej przez Anioła Interpretatora (zob. s. 178). Autor słusznie uznaje wizję czwartą za centralną i najważniejszą, gdyż jej analiza pozwala dostrzec, że „choć perspektywa tej wizji przenosi akcję do sfery transcendentnej, w której centrum stoi sam Bóg, to jednak dwaj towarzysze świecznika - młode drzewka oliwkowe - symbolizują odradzające się nowe państwo judzkie, które jest spadkobiercą obu dawnych królestw Judy i Izraela, a więc całej wspólnoty 12 pokoleń narodu wybranego. W czwartym obrazie Jahwe napełnia naród złotym, ożywczym płynem, czyli Bożym życiem, które w ziemskiej perspektywie przybierze postać żywego Słowa - Tory. Zatem sam Bóg jest tożsamością nowego Izraela i choć jest niewidzialny, to jednak dobrze słyszany za pośrednictwem Prawa, którego przepisy nie zmieniły się od chwili zawarcia Świętego Przymierza na Górze Horeb" (s. 320). W ten sposób Autor wysuwa zasadniczy wniosek, że Proto-Zachariasz w swoich proroctwach nie zmienia zasadniczo koncepcji tożsamości Izraela, postulowanej przez poprzedników. Zauważa jednak nowość przesłania proroka polegającą na tym, że jej przyjęcie nie jest zarezerwowane wyłącznie dla Żydów, ale zgodnie ze słowami Za 8,20-23 powinna ona (tożsamość) stawać się programem życia w perspektywie uniwersalnej. Zaproponowana analiza egzegetyczna i po części teologiczna nocnych wizji Proto-Zachariasza jest rzetelna i utrzymana w godnym pochwały rygoryzmie metodologicznym. Autor koncentruje uwagę czytelnika na najważniejszych elementach tekstu, nie tracąc z pola uwagi zasadniczego tematu. Jak już zauważyłem wyżej, oceniając strukturę całej publikacji, brakuje mi rozwinięcia, zwłaszcza teologicznego, tego, co Autor uznaje za novum Proto-Zachariasza, a zatem perspektywy uniwersalnej. Rodzi się także uzasad- 
nione pytanie, jak to, co postuluje prorok, ma się do uniwersalizmu obecnego wcześniej w tożsamości Izraela, o czym była mowa w pierwszym rozdziale (np. przymierza z Abrahamem). Szkoda, że zabrakło tego typu refleksji, która pozwoliłaby wyraźnie ukazać nowość prorockiego przesłania także w kontekście innych tekstów jemu współczesnych, które wyraźnie zawierają idee uniwersalne.

"Zakończenie” (s. 315-321) pracy zawiera bardzo syntetyczne przypomnienie najważniejszych etapów przebytej drogi w poszukiwaniu tożsamości Izraela od okresu Patriarchów po czasy Proto-Zachariasza oraz wniosków z analizy egzegetycznej i teologicznej siedmiu nocnych wizji proroka. Na końcu Autor wzmiankuje o dalszych możliwych kierunkach badań, do których zalicza refleksję nad recepcją myśli Zachariasza w późniejszych księgach Biblii (np. dzieło kronikarskie) oraz w pismach wspólnoty w Qumran, a także wpływ Proro-Zachariasza na Nowy Testament, zwłaszcza na Apokalipsę Janową. Zakończenie jest napisane poprawnie i nie budzi zastrzeżeń.

Po „Wykazie skrótów” (s. 323-325) odnajdujemy „Bibliografię” (s. 327-340), podzieloną poprawnie na pięć części, zawierających teksty źródłowe, pomoce słownikowe i encyklopedie, komentarze do Księgi Zachariasza, komentarze do innych ksiąg biblijnych oraz opracowania. Bibliografia został sporządzona poprawnie, choć zdarzają się pewne niekonsekwencje: niekiedy przy cytowaniu dzieł zbiorowych, brakuje podania stron; w niektórych zapisach dzieło zbiorowych brak zaznaczenia, że chodzi o redaktora, a ponadto przy cytowaniu haseł ze słowników brakuje miejsca i roku wydania poszczególnych tomów.

Warto jeszcze zauważyć, że bardzo często w monografii ks. Tułodziecki powołuje się na innych autorów, nie tylko jednak cytuje wyniki ich badań, ale potrafi krytycznie podejść do ich poglądów, ocenić je, a niejednokrotnie podjąć polemikę lub uzupełnić czy sprecyzować w oparciu o prowadzone własne analizy tekstów biblijnych. Wszystko to świadczy, że Autor nie tylko dysponuje poprawnym warsztatem badawczym, który umożliwia mu rzetelną egzegezę biblijną, zna dobrze polską i międzynarodową myśl biblijną (zwłaszcza literaturę niemieckojęzyczną), ale potrafi krytycznie korzystać z dorobku innych autorów. Warsztat badawczy oceniam bardzo wysoko, także pod względem metodologicznym. Mimo iż Autor traktuje czasami o rzeczach trudnych to jednak przejrzysty, bardzo logiczny i spójny sposób prowadzenia myśli pomaga czytelnikowi łatwiej zrozumieć prezentowane treści. Ponadto książka napisana została poprawnym i bardzo komunikatywnym językiem, co pozwala na zrozumienie jej treści nie tylko wąskiemu gronu specjalistów.

Jestem przekonany, że recenzowana monografia nie tylko znacznie wzbogaca osobisty dorobek naukowy Autora, lecz także stanie się ważnym przyczyn- 
kiem do głębszej refleksji nad tożsamością biblijnego Izraela, co z kolei może być impulsem do szukania odpowiedzi na aktualne współczesne pytania, dotyczące naszej chrześcijańskiej i polskiej tożsamości. Studium ks. Tułodzieckiego, wychodzące od tradycji biblijnej z jednej strony pozwala zrozumieć wagę i konieczność zachowania własnej tożsamości, a z drugiej strony jasno wykazuje, że troska o jej pielęgnowanie nie musi koniecznie oznaczać zamknięcia na to, co nowe i uniwersalne. 